\title{
A new approach to managing ACRL's assets
}

\author{
By Ray English and William Miller
}

\section{Using endowments to enbance ACRL's financial position}

$\mathbf{R}$ ecent changes in ALA endowment policy have made it possible for ACRL to rethink the management of its financial assets. Instead of maintaining large reserve funds, the ACRL Budget and Finance Committee is recommending to the ACRL Board a substantial transfer of funds into the ACRL and Choice endowments.

In conjunction with the endowment transfer the Committee is also proposing changes in ACRL's polices for both its endowments and its operating reserves.

We expect that these changes will:

- substantially strengthen ACRL's financial resources;

- provide more flexibility in the use of current operating funds; and

- improve ACRL's ability to carry out its strategic objectives.

The revised ALA endowment policy makes it clear that the primary purpose of ALA general endowments is to provide resources that maly be needed to respond to emergency situations and urgent needs. ALA manages and invests its endowments conservatively, with a focus on long-term growth and appreciation.

Endowment funds are to be spent only in unusual circumstances and very little income is paid out to support current operations.

In their primary purpose, ALA's endowments function in much the same way that ACRL has used its operating fund balance, particularly the portion of the fund balance that we call our "mandated operating reserve." For many years we have followed a policy of holding in reserve an amount equal to at least $40 \%$ of ACRL's recent average annual expenditures. This "rainyclay" fund, in the range of $\$ 300,000-\$ 500,000$, has always been available in the event of financial emergencies. We have also been fortunate in recent years to have surplus income, made possible by strong revenues from national conferences and publications, that has enabled the fund balance to grow to levels that are now well above the mandated reserve level.

While our past practice of maintaining such a large current fund balance has had its positive aspects, it has also had negative consequences for ACRL. The primary disadvantage is that we receive no interest or income on these current funds. According to the ALA operating agreement, all such income accrues to ALA. While it is necessary for ACRL to maintain an operating reserve that is sufficient to cover normal revenue fluctuations, having such large fund balances means that we, in effect, forgo investment income that would accrue to ACRL if the funds not needed as current reserves were invested in endowment.

Another negative consequence of the large fund balances is that they may create the incorrect impression among ACRL members that we have excess funds that could be spent for regular operations. In reality, many of ACRL's revenue streams are unpredictable and our dues revenues (which are predictable) support only a portion of basic member services. It is therefore essential that we have some funds to cover revenue fluctuations as well as others that will enable us to handle more dire emergencies.

(Endouments cont on page 397) 
ing 17 organizations attended and agreed that there was enough common ground to proceed. It was agreed that NASULGC would facilitate the development of a common agenda. Each of the six presidentially based associations will designate one college or university president to serve on a Presidents' Policy Board on Information Technology to define and promulgate policies on information technology issues and serve in an advisory role to the organizations they represent. A forum will be convened and repeated annually so that practitioners in information technology arenas and their associations may shape and inform the policies to be adopted.

The first Forum on Information Technology Policy Issues was held in Washington on March 6 and was attended by 38 delegates comprised of university presidents, chief information officers, librarians, computing center clirectors, distance education administrators, university press directors, and several association staff members. Librarians attending included ACRL's representative, Jill Fatzer, and ACRL members Elaine Albright and Sharon Hogan, who sit on NASULGC's Commission on Information Technology; also attending were Lynne Bradley from the ALA Washington Office and Pru Adler from ARL. After remarks from Magrath and Spanier on the forum's purposes, facilitator Grant Thompson led the group through an exercise to identify the most essential topics on which consensus policies will be identified. After much discussion, the areas agreed upon were copyright, clistance education, Internet enhancements, and telecommunications. Each area was assigned to a small group representative of all constituencies for the purpose of iclentifying principles on which there is substantial consensus, areas in which some negotiating might produce consensus and principles on which consensus was not possible. Each group spent several hours working up a group of principles in its area, and most found a remarkable consensus, considering the diverse interests represented.

There followed a reconvening of the entire group, which went through every draft principle to indicate whether the organization each represented could buy into it. Some redrafting occurred at this point. At the end of the day the only areas of disagreement were on subsidized telecommunications, and some aspects of fair use caused concern to the university press representatives. The next step will be a polish- ing of the statements and their presentation in a coherent document. This draft will go to the Presidents' Policy Board on Information Technology for acceptance and presentation to the associations and institutions it represents. Ultimately, the result of the effort should be more understanding of information policy issues among university presidents generally, and a clearer presentation of agreed-upon positions by many diverse associations as issues arise in Washington. Personally, it was very gratifying to see ACRL have a voice in such a potentially far-reaching endeavor.-Jill B. Fatzer

\section{(Endouments cont. from page 393)}

Since the primary purpose of the ALA general endowments is to enable ALA to respond to emergency situations, and since the present purpose of ACRL's large mandated operating reserve is essentially the same, the Budget and Finance Committee and the Board believe it makes sense to transfer to the ACRL endowments the funds in the operating reserve that have been held for more serious emergencies.

We expect that the investment income that will be produced from the larger endowments that result from the transfer will substantially strengthen the financial resources of ACRL over the long term. Modest income from the ACRL endowment will also be available to support ACRL's strategic initiatives, fulfilling to a significant extent our long-term goal for the ACRL endowment.

In view of these considerations, in San Francisco the ACRL Board will act on the following specific reconmendation from the Budget and Finance Committee:

1) that ACRL move $\$ 400,000$ from its operating fund balance and $\$ 200,000$ from Cboice's operating fund balance to the ACRL and Cboice endowments in four phased transfers over a two-year period;

2) that ACRL endowment policy be revised to conform to ALA endowment policy by including the purpose of providing financial resources that will enable ACRL to respond to emergency situations and urgent needs; and

3) that the mandated operating reserve for both ACRL and Choice be lowered to $20 \%$ of recent operating expenses.

We anticipate that this new way of maintaining our endowments and our reserves will enhance ACRL's finances and programs significantly in future years. 